\title{
Development and Implementation of Composition on the Basis of Disposed Polymer Waste
}

\author{
Shixaliyev Kerem Seyfi \\ Doctor of Technical Sciences, Professor-Academician of the European Academy of Natural Sciences \\ Professor, Department of Organic Substances and Technology of Macromolecular Compounds \\ Azerbaijan State Oil and Industry University, Baku, Azerbaijan
}

\section{ABSTRACT}

Every year, the amount of polymer products used in the country in our country is constantly growing, and these products, after use, turn into waste and cause environmental damage to our flora and fauna. The emissions of polymers used in technology are increasing year by year with the same intensity. The recycling of non-biodegradable polymer wastes is of both environmental and economic importance. However, the incomplete study of recycling methods limits the use of these valuable raw material sources. The article shows the reasons for the decommissioning of polymeric materials and analyzes the methods of recycling. Polymeric materials do not rot, do not corrode, etc. Their recycling is not only an economic problem, but also an environmental problem that needs to be addressed

KEY WORDS: WASTE, POLYMER PRODUCTS, RECYCLING, ECOLOGY, MODIFICATION, PROCESSING, BITUMEN. DESTRUCTION, POLYMER WASTE, POLYMER-BITUMEN COMPOSITION, PHYSICAL AND MECHANICAL PROPERTIES.

\section{INTRODUCTION}

Recycling of polymer waste from domestic sources is a very difficult task. It is almost impossible to organize the collection of this waste. Even if collected, there are difficulties in sorting, cleaning, shredding, washing and drying the waste. Despite all these difficulties, the recycling of polymer waste is of great environmental importance. If the structures remain and are not destroyed, it is much easier to recycle polymers of the same composition. Of course, the process of destruction is such that significant changes can occur in the macromolecule and morphology of the polymer. As a result of these changes, all the physical properties of the polymer deteriorate.

\section{ARTICLE INFORMATION}

Received 20th Oct 2020 Accepted after revision 13th Dec 2020 Print ISSN: 0974-6455 Online ISSN: 2321-4007 CODEN: BBRCBA

Thomson Reuters ISI Web of Science Clarivate Analytics USA and Crossref Indexed Journal

\section{Clarivate
Analytics}

NAAS Journal Score 2020 (4.31)

A Society of Science and Nature Publication,

Bhopal India 2020. All rights reserved.

Online Contents Available at: http//www.bbrc.in/

Doi: http://dx.doi.org/10.21786/bbrc/13.15/23
Therefore, the use of mechanical methods in the recycling of polymer waste does not give the desired results. Because during mechanical processing, macromolecules become more destructive and lose their physical and mechanical properties.

\section{RESULTS}

Taking into account the fact that there are 40-50 thousand tons of polyethylene and polystyrene waste in the republic every year, we determined that the method of their utilization is in the modification of road petroleum bitumen.

PS destruction occurs mainly as a result of high temperatures. As a result of destruction, the molecular weight of PS decreases. This can be seen more clearly in Figure -1. Polystyrene recycling and utilization methods. The reprocessing of homogeneous polymers is very simple if their structures are not destroyed. If the structure of the polymer is destroyed, then its molecular weight decreases and the physical and mechanical properties of the polymer deteriorate. If the polystyrene waste retains its original physical and mechanical properties,

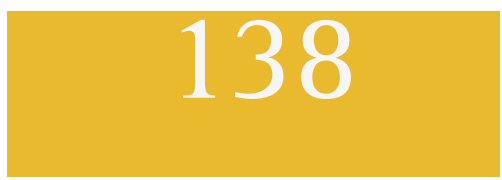


it can be used only for special purposes. Polystyrene is used in many different fields. Polystyrene is the main raw material in the production of packaging materials, coatings, electrical and electronic structures, toys and other products.

Figure 1: PS destruction in oxygenated and non-oxygenated environments 1-oxygenated, 2-oxygen-free.

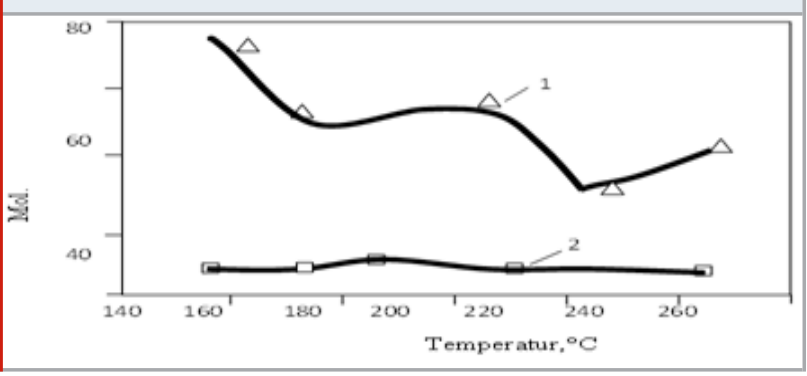

\section{DISCUSSION}

The article used the polystyrene waste shown in Table .1 to obtain a polymer-bitumen composition. 1-oxygenated, 2-oxygen-free. The joint use of PS and polyethylene waste is also of great environmental and economic importance. "Baku" brand bitumen was modified with polymer waste. The physical and mechanical properties of the obtained polymer-bitumen binder were studied by 2 modern research methods and the obtained results are given in Tables 1., .2., 3. and 4 .

3.1 Polymer-bitumen binder: Polymer-bitumen binder (PBA) is the most important element of the asphaltconcrete pavement of modern roads. The life of the road built on the basis of polymer asphalt-concrete mixture prepared using PBE is at least 7-8 years longer. Disposal to produce PBA.; Xm ;. We recommend the use of Pokr; .kaiar waste.

Table 1. Physical and mechanical properties of polymer-bitumen composition obtained with "Baku" brand petroleum bitumen modified with polystyrene waste

\begin{tabular}{|c|c|c|c|}
\hline the name of the indicator & $\begin{array}{l}\text { DÜIST } 52056203 \\
\text { requirements for. }\end{array}$ & $\begin{array}{c}\text { Bak1 bitumu " } \\
85 / 25 "\end{array}$ & $\begin{array}{l}2,5 \text { mass fraction polymer } \\
\text { bitumen composition modified } \\
\text { with polystyrene waste }\end{array}$ \\
\hline $\begin{array}{l}\text { The depth of penetration of the needle into the } \\
\text { sample, } 0.1 \mathrm{~mm} \text { at } 25^{\circ} \mathrm{C} \\
\qquad 25^{\circ} \mathrm{C} \text { - }\end{array}$ & $\begin{array}{l}60 \\
32\end{array}$ & $\begin{array}{l}74 \\
25\end{array}$ & $\begin{array}{l}62 \\
27\end{array}$ \\
\hline $\begin{array}{lll}\text { Length, } \mathrm{cm} & 25^{\circ} \mathrm{C}- \\
& 0{ }^{\circ} \mathrm{C}- & \\
\end{array}$ & $\begin{array}{l}25 \\
11 \\
\end{array}$ & $\begin{array}{l}140 \\
3,5\end{array}$ & $\begin{array}{c}103 \\
23\end{array}$ \\
\hline , softening tem ${ }^{\circ} \mathrm{C}$ & 54 & 42 & 68 \\
\hline $\begin{array}{lll}\text { elasticity } & \% & 25^{\circ} \mathrm{C}- \\
& 0^{\circ} \mathrm{C}-\mathrm{d} ə & \\
\end{array}$ & $\begin{array}{l}80 \\
70\end{array}$ & $\begin{array}{l}4 \\
3 \\
\end{array}$ & $\begin{array}{l}89 \\
70\end{array}$ \\
\hline sand and stone adhesion & \multicolumn{3}{|c|}{ sticks well } \\
\hline $135^{\circ} \mathrm{C}$ - kinematic viscosity & 455 & - & 1159 \\
\hline $60^{\circ} \mathrm{C}$ - dynamic viscosity & 270 & - & 931 \\
\hline \multicolumn{4}{|c|}{ after testing by the methodASTM P 1734} \\
\hline $\begin{array}{l}\text { Volume change, } \\
\text { blunt. by } \%\end{array}$ & - & 0,3 & 0,21 \\
\hline softening tem, ${ }^{\circ} \mathrm{C}$ & - & 604 & 1608 \\
\hline
\end{tabular}

Table 2. Polymer-bitumen modified with polyethylene waste physical and mechanical properties of the composition

\begin{tabular}{|c|c|c|c|c|}
\hline \multirow[b]{2}{*}{ the name of the indicator } & \multirow[b]{2}{*}{$\begin{array}{l}\text { DÜIST } 52056-2003 \\
\text { according to the } \\
\text { norm }\end{array}$} & \multicolumn{3}{|c|}{$\begin{array}{l}\text { The amount of PE in the polymer-bitumen } \\
\text { composition, m.f. }\end{array}$} \\
\hline & & 2 mass.f. & $\begin{array}{l}4 \\
\text { mass.f. }\end{array}$ & 6 mass.f. \\
\hline $\begin{array}{l}\text { the depth of penetration of the needle } \\
\text { into the sample, } 0,1 \mathrm{~mm} \\
25^{\circ} \mathrm{C}-\mathrm{d} \rho \\
0^{\circ} \mathrm{C}-\mathrm{d} ə\end{array}$ & $\begin{array}{l}40 \\
25\end{array}$ & $\begin{array}{l}74 \\
25\end{array}$ & $\begin{array}{l}43 \\
22\end{array}$ & $\begin{array}{l}41 \\
20\end{array}$ \\
\hline $\begin{array}{lll}\text { stretch, smo } & 0^{\circ} \mathrm{C} & 25^{\circ} \mathrm{C}-\end{array}$ & $\begin{array}{c}15 \\
8\end{array}$ & $\begin{array}{l}20 \\
3,5\end{array}$ & $\begin{array}{l}18 \\
10\end{array}$ & $\begin{array}{c}16 \\
9\end{array}$ \\
\hline softening temperature, ${ }^{\circ} \mathrm{C}$ & 56 & 64 & 68 & 72 \\
\hline brittleness temperature,${ }^{\circ} \mathrm{C}$ & -18 & -22 & -26 & -40 \\
\hline \multirow{2}{*}{$\begin{array}{c}\text { elasticity }=\% \\
25^{\circ} \mathrm{C} \text {-də } \\
0^{\circ} \mathrm{C}-\mathrm{d} ə\end{array}$} & \multirow{2}{*}{$\begin{array}{l}80 \\
70\end{array}$} & 85 & 95 & 60 \\
\hline & & \multicolumn{3}{|c|}{ not checked } \\
\hline $\begin{array}{c}\text { Change of softening temperature after } \\
\text { heating, }{ }^{\circ} \mathrm{C}\end{array}$ & 5 & 3 & 2 & 1 \\
\hline of the ignition temperature, ${ }^{\circ} \mathrm{C}$ & 210 & 300 & 320 & 350 \\
\hline Kinematic viscosity at $135^{\circ} \mathrm{C}$ & - & 455 & 4768 & 5940 \\
\hline
\end{tabular}


Table 3. Physicochemical properties of polyethylene waste

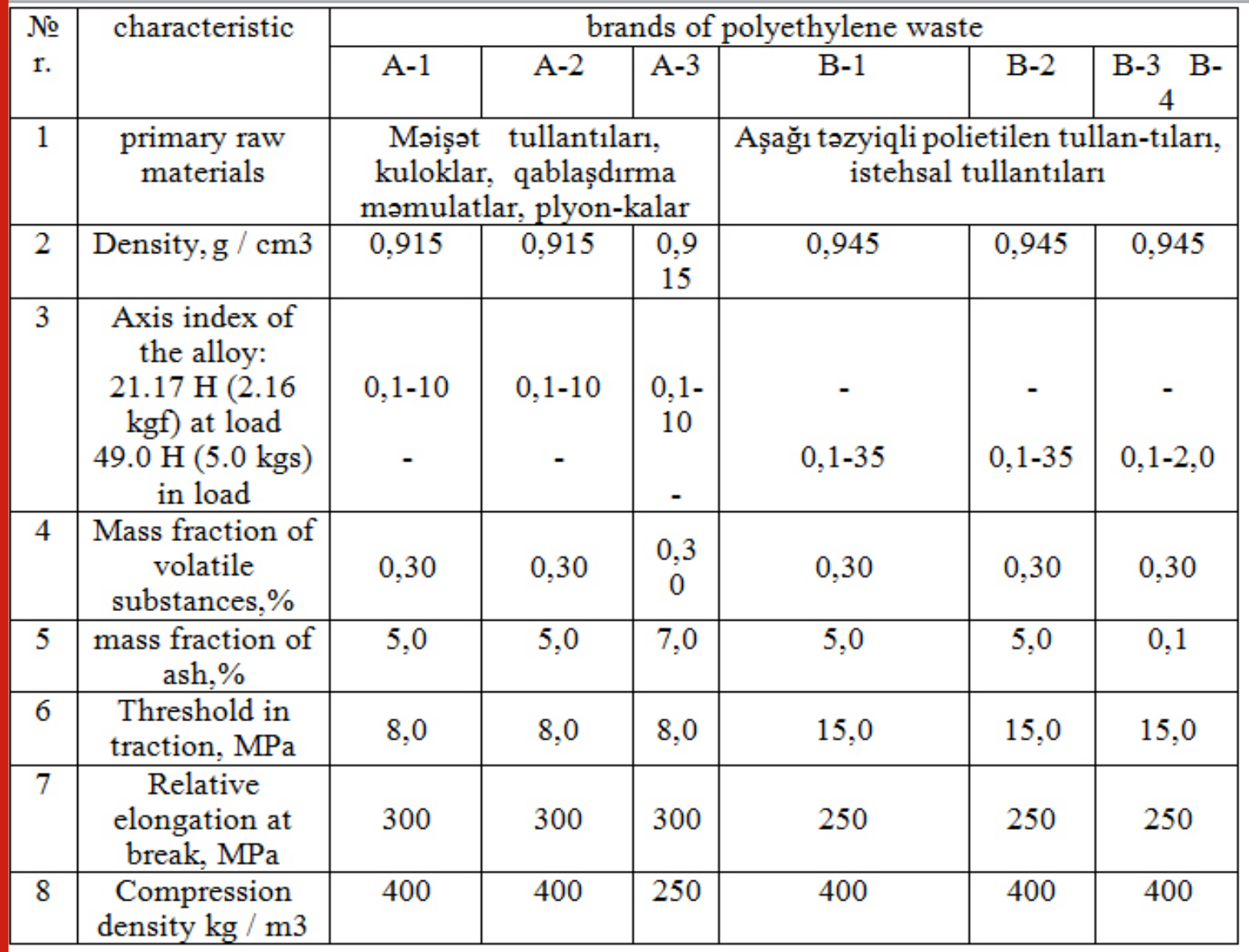

These polymer wastes repeatedly increase the basic properties of petroleum road bitumen. These indicators include durability, water and cold resistance, resistance to cracking, durability (up to $50^{\circ} \mathrm{C}$ ), resistance to displacement, etc. can be shown. Although we increase the price of asphalt concrete by 1\% using PBA, its other properties are: longevity of the road, ecological cleanliness, effective use of the road surface in accordance with world standards.

According to the state program of our republic, the construction of $5,000 \mathrm{~km}$ of roads that can meet world standards by 2035 has become the most relevant. Polymer modification is the most effective way to ensure that the physical and mechanical properties of petroleum bitumen used in road construction meet the requirements of the standards. Rubber grind | RO | The physical and mechanical properties of the polymerbitumen composition based on the properties of the original bitumen depend on it. Bitumen RO polymer is even $2.5 \% \mathrm{k}$. h. The elasticity of such a composition can be increased by more than $70 \%$ at $25^{\circ} \mathrm{C}$. RO added to bitumen dramatically increases its viscosity. As can be seen from Table 3.6, the kinematic viscosity at 135 ${ }^{\circ} \mathrm{C}$ and the dynamic viscosity at $60^{\circ} \mathrm{C}$ are blunt when Craton DT 1101CS is added with 2.5\% SBS. increases by 2.4 and 3.65 times, respectively.
SBS polymer increases the ability of bitumen to deform at $0^{\circ} \mathrm{C}$, which is 10 times higher than the deformation properties of the original bitumen. Anti-aging resistance of polymer-bitumen compositions by ASTMD 1754 method was studied. The results obtained are shown in Table 3.6. As can be seen from Table 3.5, the amount of SBS polymer in the polymer-bitumen composition is $2.5 \%$. $\mathrm{h}$ to $4.0 \% \mathrm{k}$. When raised to $\mathrm{h}$, both the kinematic viscosity and the dynamic viscosity increase. At the same time, as can be seen from Table 3.6, the physical and mechanical properties of the composition fully meet the requirements of DUIST 52058-2003.

The high structure of the polymer-bitumen binder does not allow it to be fully studied. The amount of SBS polymer in the polymer-bitumen composition is $6 \%$. When it reaches $\mathrm{h}$, the "softening temperature" increases sharply and it becomes difficult for the needle to enter the sample. Thus, by changing the amount of SBS type polymer in the polymer-bitumen binder, it is possible to obtain any characteristic modified PBA. The dispersion modified by the SBS polymer is a system (not homogeneous), ie it does not have thermodynamic stability, so it breaks down into layers. The more similar the polymer to bitumen, the more thermodynamically stable a system can be based on them. This has been proved by our experiments. Thus, a polymer-bitumen 
binder prepared in the laboratory is quickly separated into layers, while a high-efficiency mixer (Asphalt plant with P-1) is used. If PBA is prepared in a colloid mill, its dispersion can be significantly increased. As shown in Table 3.3.

Table 4. Characteristics of industrial wastes consisting of YTPE and ATPE mixtures

\begin{tabular}{|c|c|c|c|c|c|c|c|}
\hline \multirow{3}{*}{$\begin{array}{l}\text { № } \\
\text { sir. }\end{array}$} & \multirow[t]{3}{*}{ characteristic } & \multicolumn{6}{|c|}{ Industrial wastes consisting of YTPE and ATPE mixtures } \\
\hline & & \multicolumn{6}{|c|}{ Markalar: } \\
\hline & & B-1 & B-2 & B-3 & Q-1 & Q-2 & Q-3 \\
\hline 1 & primary & \multicolumn{3}{|c|}{ PE-nin sənaye tullant1lar1 } & \multicolumn{3}{|c|}{$\begin{array}{l}\text { YTPE və ATPE qarışıları əsasında } \\
\text { sənaye tullantiları }\end{array}$} \\
\hline 2 & density $\mathrm{g} / \mathrm{sm}^{3}$ & 0,915 & 0,915 & 0,915 & 0,915 & 0,915 & 0,915 \\
\hline 3 & $\begin{array}{l}\text { Flow rate of the alloy, g/ } 10 \mathrm{~min} \text {. } \\
\text { Loads: at } 21.17 \mathrm{H} \text {. } \\
\text { When } 49.0 \mathrm{H}\end{array}$ & $\begin{array}{l}0,1-35 \\
0,1-35\end{array}$ & $\begin{array}{l}0,1-35 \\
0,1-35\end{array}$ & $\begin{array}{l}0,1-35 \\
0,1-35\end{array}$ & $\begin{array}{l}0,1-35 \\
0,1-35\end{array}$ & $\begin{array}{l}0,1-35 \\
0,1-35\end{array}$ & $\begin{array}{l}0,1-35 \\
0,1-35\end{array}$ \\
\hline 4 & $\begin{array}{l}\text { Mass fraction of volatile } \\
\text { substances, } \%\end{array}$ & 0,30 & 0,30 & 0,30 & 5,0 & 5,0 & 5,0 \\
\hline 5 & Mass fraction of ash, $\%$ & 5,0 & 5,0 & 5,0 & 7,0 & 7,0 & 7,0 \\
\hline 6 & Stretch limit, MPa & 8,0 & 8,0 & 8,0 & 8,0 & 8,0 & 8,0 \\
\hline 7 & Fracture strength limit, $\mathrm{MPa}$ & 8,0 & 8,0 & 8,0 & 8,0 & 8,0 & 8,0 \\
\hline 8 & Relative elongation at break, $\%$ & 300 & 300 & 300 & 250 & 250 & 250 \\
\hline 9 & $\begin{array}{l}\text { Scattering density (kg formation), } \\
\mathrm{kg} / \mathrm{m} 3400400400300300300 \\
\text { Characteristics of industrial } \\
\text { wastes consisting of YTPE and } \\
\text { ATPE mixtures }\end{array}$ & 400 & 400 & 400 & 300 & 300 & 300 \\
\hline
\end{tabular}

Table 3.5. Polymer-bitumen obtained using SBS polymer physical and mechanical properties of the composition

\begin{tabular}{|c|c|c|c|c|c|}
\hline \multirow[b]{2}{*}{ Göstaricilarin adi } & \multirow{2}{*}{$\begin{array}{c}\text { Bak1 } 85 / 25 \\
\text { bitumun } \\
\text { göstəricilari }\end{array}$} & \multirow{2}{*}{$\begin{array}{l}\text { DÜIST } \\
52056 \\
\text { əsasən } \\
\text { tələbat }\end{array}$} & \multicolumn{3}{|c|}{$\begin{array}{l}\text { SBS-1ə modifikasiya olunmuş } \\
\text { polimer-bitum }\end{array}$} \\
\hline & & & $\begin{array}{l}2 \mathrm{k} . \mathrm{h} \\
\mathrm{SBS}\end{array}$ & $\begin{array}{l}4 \mathrm{k} . \mathrm{h} . \\
\text { SBS }\end{array}$ & $\begin{array}{l}6 \mathrm{k} . \mathrm{h} . \\
\mathrm{SBS}\end{array}$ \\
\hline $\begin{array}{l}\text { Iynənin nümunəyə girmə dərinliyi } \\
\text { (Penetrasiya), }\end{array}$ & & & & & \\
\hline $0,1 \mathrm{~mm} \quad 25^{\circ} \mathrm{C}-\mathrm{d} ə$ & $\begin{array}{l}40 \\
25\end{array}$ & $\begin{array}{l}47 \\
25\end{array}$ & $\begin{array}{l}64 \\
26\end{array}$ & $\begin{array}{l}78 \\
27\end{array}$ & $\begin{array}{l}68 \\
25\end{array}$ \\
\hline $\begin{array}{l}\text { Uzanmasi, sm } \\
0^{\circ} \mathrm{C} \text {-də }\end{array}$ & $\begin{array}{c}15 \\
8\end{array}$ & $\begin{array}{l}40 \\
3,5\end{array}$ & $\begin{array}{l}50 \\
13\end{array}$ & $\begin{array}{l}48 \\
12 \\
\end{array}$ & $\begin{array}{l}53 \\
14 \\
\end{array}$ \\
\hline Yumşalma temperaturu, ${ }^{\circ} \mathrm{C}$ & 56 & 48 & 53 & 72 & 78 \\
\hline $\begin{array}{l}\text { Q1zdırıldıqdan sonra yumuşalma } \\
\text { temperaturunun dəyişməsi, }{ }^{\circ} \mathrm{C}\end{array}$ & 3 & 2 & 2 & 1 & 1 \\
\hline Kövrəklik temperaturu, ${ }^{\circ} \mathrm{C}$ & -15 & -19 & -23 & -24 & -26 \\
\hline $\begin{array}{lll}\text { Elastiklik, } \% & 25^{\circ} \mathrm{C} \text {-də } \\
& 0{ }^{\circ} \mathrm{C} \text {-də } & \end{array}$ & $\begin{array}{l}40 \\
30\end{array}$ & $\begin{array}{l}80 \\
70\end{array}$ & $\begin{array}{l}75 \\
65\end{array}$ & $\begin{array}{l}85 \\
74\end{array}$ & $\begin{array}{l}85 \\
75\end{array}$ \\
\hline Alovlanma temperaturu, ${ }^{\circ} \mathrm{C}$ & 230 & 300 & 340 & 360 & 400 \\
\hline Quma və ya mərmərə yap1şmas1 (ilişməsi) & \multicolumn{5}{|c|}{ tələbat1 ödəyir } \\
\hline Yanğın təhlükəsi & \multicolumn{5}{|c|}{ təhlükəlidir } \\
\hline $\begin{array}{c}135^{\circ} \mathrm{C} \text {-də kinematik özlülük } \\
60^{\circ} \mathrm{C} \text {-də dinamik özlülük } \\
\end{array}$ & - & $\begin{array}{l}455 \\
210 \\
\end{array}$ & $\begin{array}{c}980 \\
1806 \\
\end{array}$ & $\begin{array}{l}1914 \\
2947\end{array}$ & $\begin{array}{l}2102 \\
3048\end{array}$ \\
\hline $\begin{array}{l}\text { ASTMD } 1754 \text { üsulu ilə həcm dəyişikliyi, \% } \\
\text { küt. }\end{array}$ & \multicolumn{5}{|c|}{ sinaq olunandan sonra } \\
\hline Qalıq penetrasiya, \% & - & 72 & 80 & 93 & 96 \\
\hline Yumșalma temperaturu, ${ }^{\circ} \mathrm{C}$ & 40 & 53 & 63 & 66 & 74 \\
\hline $25^{\circ} \mathrm{C}$ temperaturda uzanmas $1, \%$ & 110 & 47 & 45 & 38 & 32 \\
\hline
\end{tabular}




\section{CONCLUSION}

The use of HRS, mainly in the modification of petroleum bitumen, has a more significant effect. The price of HRSmodified bitumen increases by $30 \%$. The price of asphalt concrete made with modified bitumen increases by $7 \%$. However, the life of the asphalt layer of the HRS-modified bitumen pavement increases by $40 \%$, extending the service life of the road from 2 to 8 years, which saves more than $50 \%$ of the cost of repairing and rebuilding the road. Our calculations show that the city of Baku and its environs have 600,000 tons of modified road surfaces per year. When covered with asphalt concrete, it is possible to achieve 3.5 million economic benefits per year. Tehnoloji this new method is proposed etdiyimiz at the same time, are the two most important issue, but ask you to say that the use of, than those used rezin tullantılarından emalı tullantılarından and oil product is taken and ekologiyamıza eligible following the polimer and oil emalı which brings great falakat tullantılarından clean the city of Baku.

\section{REFERENCES}

Amirov F.A. Shikhaliev K.S. Talibova N.R. Evaluation of the tire exploitation process and the method of utilization of used tires, abstracts of reports YY Bakukol international conference. Baku 2009, C 276-277

Amirov F.A. Shikhaliev K.S. Talibova N.R. Study of the tire operation process and the method of utilization of used tires, abstracts of reports YY Bakukol international conference. Baku 2009, C. 276-277

Kasatkin M.M. (2000) Recycling of depreciated car tires and rubber waste. - M: Signal, , c 29-30

Obtaining an environmentally friendly composition based on polyvinyl chloride and benzyl naphthenate ether obtained from Baku oil . International Scientific and Pzactical Confrence "WORLD SCIENCE" Dubai ,UAE c5(21).Vol.1-c.46-48

Shikaliyev K.S.( 2017) Exeloited termoplastics based compositions Europeon Sciences revicw scientific journal.,-Vienna .c5-6. P.89-94

Shikaliyev K.S.( 2017) Modification of rubber mixture based on butadiene-nitrile rubber SKN-40 bu modifiled thionred Phenol-formaldehyde oliqomer Europeon
Sciences revicw scientifiic journal .,-Vienna., P. 9497

Shikhaliev K. Samirov F.A. Research of the process of obtaining coated for various purposes based on petroleum bitumen (monograph Innovative development of science and education. Under the general editorship of Yu. Gulyaev., Penza ICNS, science and education.,2017,-318 c .

Shikhaliev K.S. and others. Composite materials in the hay of rubber dust, ATY, 2003, No1, C 50-50

Shikhaliev K.S. Composition based on bitumen and rubber dust. Rubber industry. Moscow 2005,-c. 131134

Shikhaliev K.S. Ibragimova S.M. etc. Modification of bitumen with rubber-containing wastes and the use of the obtained rubber-bitumen compositions in road construction, news of VTUZA, 2008, c6, C 29-35

Shikhaliev K.S. Ibragimova S.M. etc. Modification of bitumen with rubber-containing wastes and the use of the obtained rubber-bitumen compositions in road construction, news of VTUZA, 2008, C6, C 29-35

Shikhaliev K.S. The processes of the formation of rubber dust as a result. Operation of tires. In serossiyekai scientific-practical conference rubber industry Moscow, 2005, c 131-136

Shikhaliev K.S., Amirov F.A. Theory and practice of obtaining composite materials based on polymer mixtures.REMIER pUBLIKASING.-Vienna.-2018.-164c Shikhaliev K.S., Amirov F.A., Movkhasv I.G., Talybova N.R., Mustafaeva R.E. Evaluation of the tire operation process and methods of disposal of used tires, ecoenergy, 2008. c2, - C. 33-38

Shykhaliev K.S. The problem of obtaining polymeric materials with the necessary properties for work in extreme conditions XXII international scientificpractical conference "Prospects for the development of science and education" Moscow.E-mail: www.naukaip. ru2017. C.81-90

Shykhaliev K.S., Ibragimova S.M., Bafadarova Z.M., Novruzova F.M. Modification of bitumen with rubbercontaining waste and the use of rubber-bitumen compositions in road construction. VTUZA News.: 2008. c6, - C 29-32 